\title{
Research on Innovation and Entrepreneurship Education System under the New Business Background
}

\author{
Zhi-xia ZHOU* \\ Economy and Management College \\ Weifang University \\ Weifang, China
}

Zi-yan PEI

Class 3 Grade 71

Student of Weifang First Middle School

Weifang, China

\author{
Zhi-hong ZHOU \\ Accounting Faculty \\ Shandong Economics \& Trade Vocational College \\ Weifang, China \\ Ya-zhou LI \\ Student of Economy and Management College \\ Weifang University \\ Weifang, China
}

\author{
Shu-mao Guo \\ Student of Economy and Management College \\ Weifang University \\ Weifang, China
}

\begin{abstract}
The thesis takes innovation and entrepreneurship education system in the new business background as research object, aims to cultivate college students' entrepreneurial spirit and improve their entrepreneurial skills. It adopts the method combining practical research and theoretical analysis, proposes the construct strategies: implementing the goal of Ministry of Education's industry-university cooperation and education, carrying out in-depth cooperation with enterprises to optimize the design and implementation of business innovation and entrepreneurship education system, and further innovating the talent training mechanism of applied universities. The research results can effectively cultivate innovative and entrepreneurial composite high-quality talents, which will meet regional needs and the needs of industrial development.
\end{abstract}

Keywords-industry-university cooperation; innovation and entrepreneurship; applied universities; new business background

\section{INTRODUCTION}

At present, the orientation of talent cultivation in applied universities should adapt to the changing professional needs of the society and regional economic development, and provide Internet application services such as industry information, brand communication, terminal channels and e-commerce for local industries, and then promote industrial transformation and upgrading. To improve the process of college education reform, college students' innovation and entrepreneurship activity is a powerful form, it's effective to promote education and teaching

This research was financially supported by Ministry of Education Industry-University Cooperation Collaborative Education Project (201801114030), Ministry of Education Industry-University Cooperation Collaborative Education Project(201801069109), Ministry of Education Industry-University Cooperation Collaborative Education Project (201802323013) reform, promote the reform and innovation of practical teaching and personnel training mode, and also an important indicator to test the quality of applied talents in schools ${ }^{[1]}$. How to cultivate college students' entrepreneurial spirit and improve their entrepreneurial skills in the "double creation" environment has become a hot issue in colleges and universities.

In recent years, Weifang University has cooperated with Qingdao Yinggu Education Technology Co., Ltd., Shandong Qingong Group, Shandong Hengbang Education Information Co., Ltd., Hand Hand Clothing Co., Ltd., Shandong Runtai Intelligent Electric Co., Ltd., and Shandong Wansheng Communication Co., etc. Cooperative enterprises have carried out all-round in-depth cooperation, and school-enterprise integration has jointly promoted development and innovation of applied business majors. Weifang University has formed the specialized accounting group as its core group, wich includes international economics and trade, marketing, logistics management, and economics. In 2016, it was approved as the high-level application-oriented project construction project in Shandong Province.

The project implements goal of the Ministry of Education's industry-university cooperation and education, and plans to carry out in-depth cooperation with Xindao Technology Co., to optimize the design and implementation of business innovation and entrepreneurship education system, and further innovate the talent training mechanism of our university. And form the experience and practices that can be replicated and can be promoted, so as to effectively cultivate innovative and entrepreneurial composite high-quality talents that meet regional needs and meet the needs of industrial development. 


\section{PROBLEMS IN INNOVATION AND ENTREPRENEURSHIP EDUCATION SYSTEM}

\section{A. Unreasonable Curriculum System}

The proportion of the curriculum system is unreasonable. From the perspective of the curriculum system, there are irrational phenomena such as professional foundation and core curriculum, large proportion of professional orientation courses, less practical courses, and lack of elective courses. This is inconsistent with the requirements of applying high-level talent training objectives ${ }^{[2]}$.

The course system and the corresponding post group corresponding to the "knowledge, ability, and quality" required is also relatively poor. It is recommended to set the curriculum standards to highlight the specific requirements of each module of the "knowledge, ability, and quality" of the course.

\section{B. Lack of innovation and entrepreneurship related courses}

According to the requirements of the Ministry of Education, it is necessary to guide the logistics management related college students to innovate and start a business. Therefore, both schools and enterprises should incorporate innovation and entrepreneurship education into the talent training program, so that students can master the basic knowledge needed for entrepreneurship, cultivate entrepreneurship and exercise entrepreneurial ability.

\section{Low Cooperation between Innovation and Entrepreneurship}

At present, the level of school-enterprise cooperation is mainly "come in and go out": hire enterprise experts and excellent alumni to enter the classroom; organize students to corporate trainee, professional cognition, etc. However, in the aspect of innovation and entrepreneurship education, only basic guidance work has been carried out ${ }^{[2]}$. The specific curriculum design, teaching staff, training base, maker space, incubation base, teaching material construction, talent evaluation, etc. are still very lacking. Therefore, the next step of work should be on the above topics.

\section{CONSTRUCTION GOALS OF INNOVATION AND ENTREPRENEURSHIP EDUCATION SYSTEM}

\section{A. Improving the Training Program}

Improve the training program for large business talents oriented to the cultivation of innovative entrepreneurship. Highlight the ability training of students, implement innovative credits, and equip with project instructors to develop students' vision through the teacher class and practical semester, improve students' practical ability, and promote the reform of innovation and entrepreneurship education guided by ability training [3].

\section{B. Developing the Curriculum System}

Develop and build a large business innovation and entrepreneurship education curriculum system. Develop innovative and entrepreneurial training programs such as enterprise expert classrooms, entrepreneurship practice training, "Entrepreneurial Way", and compile and use a series of teaching guidance documents, teaching materials and other teaching materials.

\section{Establishing the Guidance Office}

Establish an Innovation and Entrepreneurship Guidance Office to carry out innovation and entrepreneurship guidance. Further screening of entrepreneurial projects supported by government departments, industry associations, and related companies will provide more opportunities for college students to participate in entrepreneurial activities, participate in innovative activities, and implement entrepreneurial processes.

\section{Establishing the Teaching Platform}

Establish school-enterprise collaborative teaching platform to create a practice base for innovation and entrepreneurship education. Establish and improve the school-enterprise collaborative teaching platform to improve students' ability of innovation and entrepreneurship; combined with the characteristics of each specialty, build a multi-angle, all-round, and full-process evaluation feedback mechanism based on the business innovation and entrepreneurship practice teaching, and scientifically evaluate the implementation effect of innovation and entrepreneurship education ${ }^{[4]}$.

\section{CONSTRUCTION CONTENT AND IMPLEMENTATION PATH}

\section{A. Building Innovation and Entrepreneurship Curriculum System}

Build a modular innovation and entrepreneurship curriculum system and carry out multi-level innovation and entrepreneurship education. Construct a multi-level modular innovation and entrepreneurship education curriculum system for large business majors, and carry out entrepreneurship education training in sub-modules, including curriculum innovation and innovation, entrepreneurship promotion, innovation and entrepreneurship practice. The first level provides a comprehensive curriculum for innovation and entrepreneurship education, which aims to cultivate college students' entrepreneurial awareness and entrepreneurial spirit. The second level provides innovative and entrepreneurial education skills curriculum modules to meet the individualized requirements of students' entrepreneurial skills and ability improvement ${ }^{[5]}$. The level of innovation and entrepreneurship education practice curriculum module is designed to cultivate students' ability to practice innovation.

\section{B. Building High-Quality and Professional Faculty Team}

Build a team of high-quality innovative entrepreneurial instructors and form a professional faculty team. Establish a library of innovative and entrepreneurial instructors, and hire industry leaders, entrepreneurs, entrepreneurs, experts and scholars, outstanding entrepreneurial alumni and qualified faculty and staff as innovative entrepreneurs. At present, the school has 120 innovative and entrepreneurial tutors, including 54 outside tutors $(45 \%)$. The next step is to further increase the proportion of social industry instructors through the 
cooperation with Xindao Technology Co., Ltd., and create a stronger team of entrepreneurial teachers. Jointly carry out innovative and entrepreneurial practice activities of network marketing, innovation awareness and product optimization.

\section{Building the Practical Teaching System}

Build the practical teaching system of "disciplinary competition, innovative training, entrepreneurial practice" to guide students to innovate and start a business. Established the Office of Innovation and Entrepreneurship of the School of Economics and Management, organized and implemented innovation and entrepreneurship activities at different levels, and the senior instructors of innovation and entrepreneurship assisted students in participating in the National College Students Innovation and Entrepreneurship Training Program, the Ministry of Education "Internet Plus" College Students Innovation and Entrepreneurship Competition and the Shandong University Students Science and Technology Festival in the competition, the young and instructors of innovation and entrepreneurship will help students to participate in the "Challenge Cup", "Creating Youth" and the Student Research and Training Program (SRTP). The large business professional tutors will help students participate in the National University Student Network Business Innovation Application Competition and the national college students' ecommerce "innovation". The Creative, Entrepreneurship Challenge, National Undergraduate Innovation and Entrepreneurship Sandbox Simulation Business Competition and other discipline competitions, multi-dimensional guidance for students to innovate and start a business.

\section{Building Innovation and Entrepreneurship Education Base}

Build a base for innovation and entrepreneurship education, and improve the mode and mechanism of school-enterprise collaborative training. Establish and improve the schoolenterprise collaborative teaching platform, cooperate with the China Internet Association to establish a school-enterprise practice teaching platform, carry out entrepreneurial practice based on real industry issues; cooperate with Xindao Technology Co., Ltd. to open a business project platform, and carry out entrepreneurial quality development training. Through extensive cooperation between "school and enterprise construction", we will establish a 5R system that strengthens the cultivation of practical and innovative abilities, that is, the real working environment, training programs, project managers, work pressures and job opportunities ${ }^{[6]}$, effectively enhancing the awareness of innovation and entrepreneurship.

\section{E. Promoting the Practical Conditions Construction}

Promote the construction of practical conditions for innovation and entrepreneurship, and improve the training environment for innovation and entrepreneurship. Relying on the school and Xindao Technology Co., Ltd., increase the investment in experimental funds and improve the experimental teaching conditions. According to the characteristics of business majors, research and establish the task requirements of college students' business innovation and entrepreneurship laboratories, formulate specific plans for laboratory construction, and build an entrepreneurial education ecosystem. Adhere to the national strategy and regional economic and social development as the orientation of the demand for innovative talents, strengthen service awareness, effectively attract social resources to the school, and promote the effective incubation of college students' innovation and entrepreneurial achievements ${ }^{[7]}$.

The specific implementation path of the construction is as follows (see Fig. 1):

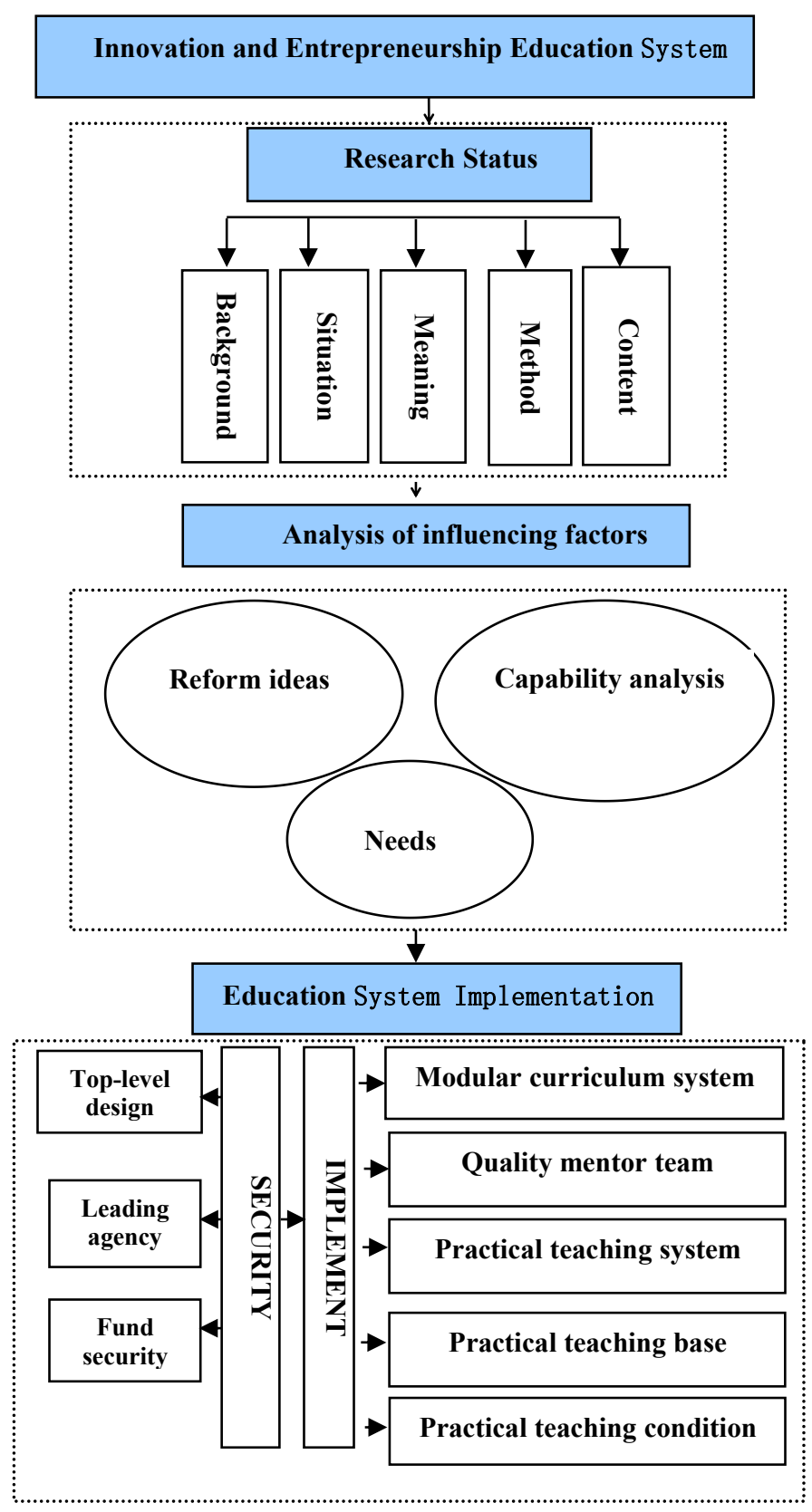

Fig. 1. Implementation path for education system 


\section{IMPLEMENTATION SUGGESTIONS ON INNOVATIVE ENTREPRENEURSHIP EDUCATION SYSTEM}

\section{A. Constructing the Teaching System}

Construct a "five in one" teaching system for courses, lecture halls, training, competitions, and results incubation. Based on the diverse development needs of students, it not only teaches innovation and entrepreneurship knowledge to all students, but also classifies students who are interested in entrepreneurship to cultivate innovative entrepreneurship spirit and ability. Based on the innovation and entrepreneurship curriculum, supplemented by Innovation and Entrepreneurship Lecture Hall, the annual innovation and entrepreneurship education lectures, salons, workshops and other activities will be held to broaden students' horizons and stimulate students' interest. Taking innovation and entrepreneurship training as the starting point, taking the innovation and entrepreneurial competition as the platform, promoting competition and promoting competition by teaching, and guiding students to participate in various innovation and entrepreneurial competitions and academic competitions. With the help of innovation and entrepreneurship incubation, we will help entrepreneurial students to carry out entrepreneurial practice, and support student entrepreneurship projects.

\section{B. Creating the Practical Platform}

Create a practical platform for innovation, creativity, creativity, and entrepreneurship. Planning and construction the "Four Creation Space" provides conditions for students to exchange ideas and experiences and practice whimsy of innovation and entrepreneurship. Based on "Internet + ", build innovative research centers, "Internet + " big data labs and other innovative training centers. For the cultural industry, set up creative studios such as visual creative workshops and cultural and creative research centers. Dock the market, set up various types of venture funds, incentive funds and special education funds to gather entrepreneurial elements such as teachers, students, funds, venues, legal affairs, etc., to encourage and support students to carry out entrepreneurial practice.

\section{Deepening the synergistic education mechanism}

Deepen the school-school collaboration, school-enterprise collaboration, and school-site synergy "three synergies" education mechanism. Actively attract social resources and high-quality educational resources abroad, and jointly develop innovative and entrepreneurial talents. Strengthen schoolschool collaboration, strengthen cooperation with relevant universities in the United States and the United Kingdom, and bring together internationally renowned experts, successful entrepreneurs, and famous investors to carry out innovation and entrepreneurship education and training. Strengthen the coordination between schools and enterprises, hire experts from various industries to set up a library of innovative and entrepreneurial instructors, consult and demonstrate the innovation and entrepreneurship education in schools, and provide professional counseling for students' innovation and entrepreneurship practices. Strengthen the coordination of school and campus, make full use of the cooperation platform of government, industry, research and research, research and development institutions and technological innovation alliances, build a student entrepreneurship practice training base, and enhance students' ability of innovation and entrepreneurship in serving local economic and social development.

\section{CONCLUSION}

The application-based undergraduate college innovation and entrepreneurship curriculum system constructed by this project has certain practical application value. The project establishes the concept of talent cultivation oriented by innovation and entrepreneurship, and develops and builds a multi-level modular innovation and entrepreneurship education curriculum system for large business majors, and builds a threedimensional, full-scale innovation and entrepreneurship education framework for students, enterprises and universities. The multi-level modular curriculum system can fully realize the synergy of the three dimensions of knowledge, skills and emotions in the dual-innovation education, and effectively improve the training quality of the compound talents in the applied undergraduate colleges.

The trinity practice teaching system of "disciplinary competition, innovation training, entrepreneurial practice" constructed by this project has certain practical application significance. The project actively carries out various forms of innovative and entrepreneurial teaching activities, organizes students to participate in various national and provincial innovation and entrepreneurship competitions and academic competitions, and has formed a competition mode with high integration and strong application of various professions, which can be comprehensively improved. Students practice application ability and innovation and entrepreneurship, and effectively promote the close integration of higher education with science and technology, economy and society.

\section{ACKNOWLEDGEMENT}

This research was financially supported by Ministry of Education Industry-University Cooperation Collaborative Education Project (201801114030), Ministry of Education Industry-University Cooperation Collaborative Education Project (201801069109), Ministry of Education IndustryUniversity Cooperation Collaborative Education Project (201802323013).

\section{REFERENCES}

[1] Chen Xiaozhu, "Innovation and entrepreneurship education for college students in the age of creation", China Higher Education, vol. 4, 2015, pp. 23-28 (In Chinese)

[2] Yan Jianhua,"Construct innovation based entrepreneurship education”, China Higher Education, vol. 6, 2016, pp. 38-42 (In Chinese)

[3] Tian Juanjuan, "Discussion on the cultivation of financial professionals in the context of new business," Co-Operative Economy \& Science, vol. 4, 2019, pp. 112-113 (In Chinese)

[4] Zeng Wei, Zhang Zhongqiu, Liu Yannan, "The double innovative strategy of innovation and entrepreneurship education in universities needs synergic development", Educational Research, vol. 11, 2018, pp. 174-176 (In Chinese). 
[5] Ren Jiajia, "Research on the construction of practical teaching system for e-commerce in applied undergraduate colleges," E-Business Journal, vol. 5, 2019, pp. 69-70 (In Chinese).

[6] Wang Zhanren, "Research on the disciplinary characteristics and development orientation of innovation and entrepreneurship education in
Chinese universities", Educational Research, vol. 9, 2016, pp. $78-79$ (In Chinese)

[7] Xue Chenglong, "Review on innovation and entrepreneurship education in colleges and universities during the twelfth five-year plan period," China Higher Education Research, vol. 7, 2016, pp. 118-119 (In Chinese). 